\title{
PENERAPAN MODEL PEMBELAJARAN KOOPERATIF KANCING GAMERINCING TERHADAP PENINGKATAN MINAT DAN HASIL BELAJAR PESERTA DIDIK
}

\author{
Safril Tiangka, Muhammad Qaddafi, Suhardiman \\ Fakultas Tarbiyah dan Keguruan UIN Alauddin Makassar, safrilneymar17@gmail.com
}

\begin{abstract}
Abstrak:
Penelitian ini merupakan penelitian Pre-Eksperimen Design yang bertujuan untuk mengetahui: 1) Minat dan hasil belajar peserta didik yang diajar dengan model pembelajaran Koopeartif kancing gamerincing peserta didik pada kelas VIII SMP Negeri 1 Baraka, 2) Minat dan hasil belajar peserta didik yang tidak diajar dengan model pembelajaran Koopeartif kancing gamerincing peserta didik pada kelas VIII SMP Negeri 1 Baraka, 3) peningkatan minat dan hasil belajar peserta didik antara yang diajar dan yang tidak diajar dengan model pembelajaran Koopeartif kancing gamerincing peserta didik pada kelas VIII SMP N Negeri 1 Baraka. Desain penelitian yang digunakan adalah Intac-Group Comparison Design. Hasil penelitan menunjukkan bahwa terdapat peningkatan minat dan hasil belajar peserta didik antara kelas yang diajar dan yang tidak diajar dengan model pembelajaran koopeartif pada kelas VIII SMP Negeri 1 Baraka Kabupaten Enrekang.
\end{abstract}

Kata Kunci : Kooperatif; Gamerincin; Minat; Hasil Belajar

\begin{abstract}
Pendahuluan
Proses pencapaian tujuan pendidikan nasional, maka pemerintah berupaya meningkatkan mutu pendidikan mulai dari jenjang sekolah dasar sampai perguruan tinggi. Pembelajaran Ilmu Pengetahuan Alam (IPA) khususnya fisika merupakan salah satu mata pelajaran yang bermanfaat bagi suatu bangsa. Kesejatraan materi suatu bangsa, banyak bergantung pada kemampuan bangsa dalam pembelajaran (IPA), sebab merupakan dasar teknologi, sedangkan teknologi sering disebut sebagai tulang punggung pembangunan Belajar IPA bukan sekedar menghapal teori dan rumus saja akan tetapi, juga menggunakan keterampilan proses IPA seperti menghubungkan dengan dunia nyata.
\end{abstract}

Seorang guru dianjurkan agar terampil memilih dan menggunakan model, media serta strategi pembelajaran yang sesuai dengan materi pembelajaran yang diajarkan sehingga siswa mudah memahami pelajaran tersebut. Strategi dalam pembelajaran terbagi atas dua bagian yaitu strategi yang berpusat pada guru dan strategi yang berpusat pada siswa.

Model pembelajaran yang digunakan dalam proses pembelajaran harus dapat membuat pelajaran IPA khususnya fisika, terasa mudah dan menyenangkan. Pembelajaran IPA fisika hendaknya dikaitkan seoptimal mungkin dengan kehidupan nyata sehingga bermakna dalam kehidupan peserta didik yang abstrak, mengadakan variasi dalam kegiatan pembelajaran memberi kesempatan pada peserta didik serta bertahab mandiri dalam belajar dan berpartisipasi secara aktif dalam proses pembelajaran, mengadakan evaluasi dan umpan balik serta memberi penguatan pada peserta didik

Sebelumnya peneliti melakukan observasi di SMP Negeri 1 Baraka dengan melihat langsung proses pembelajaran yang berlangsung di kelas. Salah satu guru mata pelajaran fisika, mengatakan bahwa kebanyakan siswa hanya mengikuti mata pelajaran yang sedang berlangsung sedangkan dalam memperhatikan penjelasan guru, menjawab pertanyaan, mengajukan pertanyaan dan mengerjakan tugas-tugas yang diberikan masih sangat kurang. Sehingga siswa kurang termotivasi untuk belajar.

Melihat permasalahan di atas, maka perlu segera dicarikan solusinya untuk meningkatkan minat belajar peserta didik. Salah satu cara yang dapat digunakan dan diduga dapat meningkatkan minat belajar peserta didik adalah menerapkan model pembelajaran kooperatif kancing gamerincing

Menurut Trianto (2017: 51), Model pembelajaran merupakan suatu perencanaan atau suatu pola yang digunakan sebagai pedoman dalam merencanakan pembelajaran di kelas atau pembelajaran tutorial. Model pembelajaran mengacu pada pendekatan pembelajaran yang 
digunakan, termasuk di dalamnya tujuan-tujuan pengajaran.

Pembelajaran kooperatif merupakan model pembelajaran dengan menggunakan system pengelompokan/tim kecil, yaitu antara empat sampai dengan enam orang yang mempunyai latar belakang kemampuan akademis, jenis kelamin, ras, atau suku yang berbeda (heterogen). Sistem penilaian dilakukan terhadap kelompok. Setiap kelompok akan menerima penghargaan (reward), jika kelompok mampu menunjukkan prestasi yang dipersyaratkan (Wina Sanjaya, 2008: 194).

Model teknik kancing gemerincing merupakan kegiatan mengajar dengan memberikan kesempatan kepada seluruh peserta didik melalui alat bantu berupa kancing atau manik-manik dan alat lain yang menarik bagi siswa untuk mengungkapkan gagasan, pendapat maupun saran sehingga tidak ada yang dominanmenyatakan keraguan, menjawab pertanyaan, bertanya, mengungkapkan ide, mengklarifikasi pertanyaan, mengklarifikasi ide, merangkum, mendorong partisipasi anggota lainnya, memberikan penghargaan untuk ide yang dikemukakan anggota lainnya dengan mengatakan hal yang positif (Bhakti, 2012: 7).

Teknik kancing gemerincing merupakan teknik pembelajaran yang menggunakan kancingkancing sebagai media untuk mengatur pola interaksi siswa dalam kelompok belajar. Kegiatan pembelajaran pada teknik kancing gemerincing memberi kesempatan kepada siswa untuk memberikan kontribusi mereka serta mendengarkan pandangan dan pemikiran siswa lain dalam satu kelompok (Nurjannah, , 2013: 4).

Berdasarkan latar belakang dan kajian pustaka maka perlu dilakukan penelitian yang bertujuan untuk: 1) Untuk mengetahui minat dan hasil belajar siswa kelas yang diajar dengan model pembelajaran kooperatif kancing gamerincing peserta didik pada kelas VIII SMP Negeri 1 Baraka. 2) Untuk mengetahui minat dan hasil belajar siswa kelas yang tidak diajar dengan model pembelajaran kooperatif kancing gamerincing peserta didik pada kelas VIII SMP Negeri 1 Baraka. 3) Untuk mengetahui apakah terdapat peningkatan minat dan hasil belajar peserta didik antara kelas yang diajar dan yang tidak diajar dengan model pembelajaran kooperatif kancing gamerincing peserta didik pada kelas VIII SMP Negeri 1 Baraka.
Dengan menerapkan model pembelajaran koopeartif kancing gamerincing diharapkan memberikan manfaat: Bagi Siswa, diharapkan dapat dijadikan sebagai bahan pembelajaran yang dapat digunakan untuk meningkatkan minat belajar dan hasil belajar siswa khususnya mata pelajaran fisika. Bagi guru, diharapkan dapat bahan masukan bagi guru khususnya guru fisika tentang variabel-variabel yang mempengaruhi minat belajar sehingga guru dapat mengarahkan siswa untuk dapat termotivasi dalam belajar serta bahan informasi dan bahan acuan dalam mengembangkan model pembelajaran yang sesuai dengan bahan pembelajaran fisika. Bagi sekolah, diharapkan dapat dijadikan sebagai bahan pembelajaran yang dapat digunakan untuk meningkatkan minat belajar dan hasil belajar siswa khususnya mata pelajaran fisika

\section{Metodologi}

Penelitian ini termasuk dalam preExperimental dan Desain penelitian yang digunakan yaitu Intac-Group Comparison Design, di mana pada desain ini terdiri atas dua kelompok, satu kelompok untuk eksperimen (yang diberi perlakuan) dan satu untuk kelompok kontrol (yang tidak diberi perlakuan) pada keduanya dilakukan pasca-uji dan hasilnya dibandingkan. Penelitian ini dilaksanakan di SMP Negeri 1 Baraka, dengan populasi penelitian seluruh siswa kelas VIII SMP Negeri 1 Baraka yang berjumlah 171 orang yang tersebar dalam 7 kelas. Sampel penelitian berjumlah 48 orang yang dipilih dari dua kelas dengan menggunakan teknik convenience sampling. Mata pelajaran yang digunakan untuk penelitian adalah mata pelajaran Sistem tata Surya dan Kehidupan Bumi. Prosedur penelitian yang diterapkan berupa persiapan, pelaksanaan, pengolahan data dan pelaporan hasil.

Data yang dikumpulkan dalam penelitian ini meliputi: data tentang minat dan hasil belajar peserta didik yang diajar dengan model pembelajaran koopeartif kancing gamerincing.

Teknik analisis data yang digunakan meliputi analisis statistik deskriptif dan analisis statistik inferensial. Data yang diperoleh melalui instrumen penelitian berupa tes untuk mengukur hasil belajar peserta didik dan skala minat belajar untuk mengukur minat belajar peserta didik. 


\section{Hasil dan Pembahasan}

\section{Minat Belajar}

Berdasarkan hasil observasi minat belajar peserta didik maka diperoleh data minat belajar yang dapat dilihat pada tabel berikut.

Tabel.Nilai rata-rata kelas sampel

\begin{tabular}{lcc} 
& Ekspe & Kont \\
\hline $\mathrm{N}$ & 24 & 24 \\
$\mathrm{X}$ & 87,17 & 79,5 \\
\hline To & & 3,50 \\
\hline $\mathrm{t}_{\text {tabel }}$ & \multicolumn{3}{c}{2,07} &
\end{tabular}

Hasil pengujian hipotesis dengan menggunakan uji t-2 sampel independent diperoleh $t_{\text {Hitung }}$ sebesar 3,50 dan nilai $t_{\text {tabel }}$ sebesar 2,07. Hal ini terlihat bahwa nilai $t_{\text {hitung }}=$ $3,50>\mathrm{t}_{\text {tabel }}=2,07$ sehingga dapat disimpulkan bahwa $\mathrm{H}_{0}$ ditolak dan $\mathrm{H}_{\mathrm{a}}$ diterima yaitu ada peningkatan minat belajar fisika yang dimiliki peserta didik, antara peserta didik yang diajar model pembelajaran kooperatif kancing gamerincing dengan yang tidak diajar dengan model pembelajaran koopeartif kancing gamerincing peserta didik pada kelas VIII SMP Negeri 1 Baraka. Hal ini menunjukkan bahwa minat belajar fisika yang diajar dengan model pembelajaran kooperatif kancing gamerincing berbeda dengan minat belajar fisika peserta didik yang tidak diajar dengan model pembelajaran kooperatif kancing gamerincing dikatakan efektif.

Hasil penelitian menujukkan bahwa terdapat peningkatan minat belajar fisika antara peserta didik yang diajar dengan model pembelajaran koopeartif kancing gamerincing peserta didik, yang diajar dan tidak diajar dengan model pembelajaran koopeartif kancing gamerincing. Hal ini berdasarkan pada hasil analisis uji t-2 sampel independent di mana diperoleh nilai $t_{\text {hitung }}$ yang lebih besar dibandingkan dengan nilai $t_{\text {tabel. }}$. Berdasarkan hasil tersebut, maka pengambilan kesimpulan hipotesis yaitu $\mathrm{H}_{0}$ ditolak dan hipotesis atau $\mathrm{H}_{\mathrm{a}}$ diterima. Dengan kata lain, terdapat peningkatan minat belajar fisika peserta didik antara kelas yang diajar dengan model pembelajaran koopeartif kancing gamerincing dengan kelas yang tidak diajar dengan model pembelajaran koopeartif kancing gamerincing.

Perbedaan minat belajar peserta didik antara yang diajar dan yang tidak diajar menggunakan model pembelajaran kooperatif kancing gamerincing dapat dipengaruhi oleh beberapa faktor diantaranya adanya perbedaan perlakuan yang diberikan dimana kelas eksperimen (VIII C) diajar dengan menggunakan model pembelajaran yang merupakan gabungan dari model pembelajaran dan metode pembelajaran yaitu model pembelajaran kooperatif kancing gamerincing. Model pembelajaran kooperatif merupakan model pembelajaran yang menuntun para siswa untuk dapat berinteraksi dan bekerja sama dengan siswa yang lain untuk dapat bekerja sama dalam membangun pengetahuan awal mereka. Model pembelajaran kancing gamerincing merupakan model pembelajaran dengan kegiatan mengajar dengan memberikan kesempatan kepada seluruh peserta didik melalui alat bantu berupa kancing atau manik-manik dan alat lain yang menarik bagi siswa untuk mengungkapkan gagasan, pendapat maupun saran sehingga tidak ada yang dominan menyatakan keraguan, menjawab pertanyaan, bertanya, mengungkapkan ide, mengklarifikasi pertanyaan, mengklarifikasi ide, merangkum, mendorong partisipasi anggota lainnya, memberikan penghargaan untuk ide yang dikemukakan anggota lainnya dengan mengatakan hal yang positif. Model pembelajaran ini merupakan salah satu model pembelajaran yang baik untuk menarik minat dan menciptakan suatu keinginan yang besar dalam diri peserta didik untuk mempelajari fisika. Sedangkan metode kancing merupakan metode belajar menggunakan kancing sebagai alat bantu untuk berpendapat dalam proses pembelajaran.

\section{Hasil Belajar}

Berdasarkan hasil observasi hasil belajar peserta didik maka diperoleh data hasil belajar yang dapat dilihat pada tabel berikut.

Tabel.Nilai rata-rata kelas sampel

\begin{tabular}{lcc} 
& Eksp & Kont \\
\hline $\mathrm{N}$ & 24 & 24 \\
\hline $\mathrm{X}$ & 83,58 & \\
\hline To & \multicolumn{3}{c}{6,28} \\
\hline $\mathrm{t}_{\text {tabel }}$ & \multicolumn{3}{c}{2,07}
\end{tabular}


Hasil pengujian hipotesis dengan menggunakan uji t-2 sampel independent diperoleh $t_{\text {Hitung }}$ sebesar 6,28 dan nilai $t_{\text {tabel }}$ sebesar 2,07. Hal ini terlihat bahwa nilai $t_{\text {hitung }}=$ $6,28>t_{\text {tabel }}=2,021$. sehingga dapat disimpulkan bahwa Ho ditolak dan Ha diterima, dengan kata lain, terdapat peningkatan yang signifikan hasil belajar yang dimiliki peserta didik antara peserta didik yang diajar dengan model pembelajaran kooperatif kancing gamerincing dengan peserta didik yang tidak diajar dengan menggunakan model pembelajaran kooperatif kancing gamerincing peserta didik pada materi fisika kelas VIII SMP Negeri 1 Baraka Kabupaten Enrekang. Hal ini menunjukkan bahwa hasil belajar fisika peserta didik yang diajar dengan model pembelajaran kooperatif kancing gamerincing berbeda dengan hasil belajar fisika peserta didik yang tidak diajar dengan model pembelajaran kooperatif kancing gamerincing pada materi fisika sistem tata surya dan kehidupan bumi pada kelas VIII SMP Negeri 1 Baraka Kabupaten Enrekang.

Hasil penelitian ini menujukkan bahwa terdapat peningkatan yang signifikan hasil belajar fisika antara peserta didik yang diajar dengan menggunakan model pembelajaran koopeartif kancing gamerincing dan peserta didik yang tidak diajar dengan model pembelajaran koopeartif kancing gamerincing peserta didik kelas VIII SMP Negeri 1 Baraka Kabupaten Enrekang. Hal ini berdasarkan pada hasil analisis uji t-2 sampel independent dengan persamaan uji Gain yaitu selisih nilai sesudah dan sebelum di beri suau perlakuan di mana diperoleh nilai $t_{\text {hitung yang lebih besar }}$ dibandingkan dengan nilai $t_{\text {tabel. }}$. Berdasarkan hasil tersebut, maka pengambilan kesimpulan hipotesis yaitu $\mathrm{H}_{0}$ ditolak dan hipotesis atau $\mathrm{H}_{\mathrm{a}}$ diterima. Dengan kata lain, terdapat perbedaan antara hasil belajar fisika peserta didik kelas yang diajar dengan menggunakan model pembelajaran koopeartif kancing gamerincing dengan kelas yang tidak diajar dengan model pembelajaran koopeartif kancing gamerincing.

Dari uraian, diatas maka dapat disimpulkan bahwa pembelajaran dengan menggunakan model pembelajaran koopeartif kancing gamerincing memberikan pengaruh yang berarti terhadap minat dan hasil belajar peserta didik pada kelas VIII SMP Negeri 1 Baraka
Kabupaten Enrekang. Dengan demikian pembelajaran dengan menggunakan model pembelajaran koopeartif kancing gamerincing telah dibuktikan secara statistik dapat menjawab permasalahan dalam penelitian ini, sehingga hipotesis (Ho) di tolak dan (Ha) di terimah.

\section{Kesimpulan}

Berdasarkan penelitian yang telah dilakukan, adapun kesimpulan yang dipaparkan sebagai berikut: 1) Minat belajar fisika peserta didik yang diajar dengan Model pembelajaran koopeartif kancing gamerincing berada pada kategorisasi tinggi dan hasil belajar fisika peserta didik yang diajar dengan model pembelajaran kooperatif kancing gamerincing dapat dilihat berada pada kategorisasi tinggi. 2) Minat belajar fisika peserta didik yang tidak diajar dengan model pembelajaran koopeartif kancing gamerincing berada pada kategorisasi sedang dan hasil belajar fisika peserta didik yang tidak diajar dengan Model pembelajaran koopeartif kancing gamerincing berada pada kategorisasi sedang dan tinggi. 3) Terdapat peningkatan yang signifikan minat dan hasil belajar fisika antara peserta didik yang diajar dengan menggunakan model pembelajaran koopeartif kancing gamerincing dan kelas yang tidak diajar dengan menggunaka model pembelajaran koopeartif kancing gamerincing.

\section{Daftar Rujukan}

Azwar, Saifuddin, 2012. Penyusunan Skala Psikologi. Pustaka Pelajar, yogjakarta.

Kurnia. Penerapan Metode Struktural Teknik Kancing Gamerincing dalam Meningkatkan Keaktifan Siswa pada Materi Pelajaran IPS Bagi Siswa Kelas VII SDN Bayuurip Klego tahun ajaran 2012/2013. Jakarta: Universitas Muhammadiyah.

Misbahuddin dan Hasan. 2013. Analisis Data Penelitian dengan Statistik. Jakarta: PT Aksara.

Sanjaya, Wina, 2008, Strategi Pembelajaran Beriorentasi Standar proses Pendidikan, Kencana, Jakarta.

Sugiyono, 2013, Penelitian Kualitatif dan Kuantitatif, Alfabeta, Bandung. 
Syofian Sireger. Statistik Parametrik untuk Penelitian Kuantitatif. Jakarta: Bumi Aksara, 2014.

Trianto, Ari. 2017. Model Pembelajaran Terpadu Dalam Teori Dan Praktek. Prestasi Pustaka Publisher. Jakarta. 